\title{
Is non-executive directors' pay or industry expertise related to takeover premiums, abnormal returns and offer price revisions?
}

\author{
Martin Bugeja \\ University of Technology Sydney \\ Zoltan Matolcsy \\ University of Technology Sydney \\ Wassila Mehdi \\ University of Technology Sydney \\ Helen Spiropoulos \\ University of Technology Sydney
}

\begin{abstract}
We examine the association between various takeover outcomes and bidding firm nonexecutive director (NEDs) compensation and expertise in the target firm industry. In our sample of 272 acquisitions by ASX listed firms between 2004-2011, we find that NEDs' relative compensation and industry expertise have a negative association with the bid premium. We also find that NEDs' relative compensation is positively associated with the bidding firm's market reaction to the takeover announcement, and NEDs' industry expertise is associated with a lower likelihood of an increase in the offer price, particularly for M\&As viewed negatively by the market. These results are consistent with higher NEDs' relative compensation and industry expertise leading to more effective board monitoring and advising.
\end{abstract}

Keywords: NEDs, Compensation, Industry Expertise, M\&As, Bid premium, CAR, Market reaction. 


\section{Introduction}

There is an emerging literature which focuses on the influence of non-executive directors' (NEDs') incentives, attributes and/or expertise on various corporate decisions. ${ }^{1}$ For example, Masulis and Mobbs (2014) find that non-executive or independent directors' attendance is higher for their directorships at larger more 'prestigious' firms as these directorships lead to greater enhancements to a director's reputational capital. Additionally, Larcker et al. (2013) suggest that NEDs' connectedness matters and that it results in improved firm performance. This study builds on this stream of literature by examining the link between bidding firm NEDs' relative compensation and industry expertise and different aspects of mergers and acquisitions (M\&A). Specifically, our three objectives are to provide evidence on the association between NEDs' relative compensation and industry expertise and: (i) takeover premiums; (ii) the market reaction to the takeover announcement, and; (iii) the likelihood of a change in the offer price.

The motivation for this study is twofold. First, the incentive for NEDs to monitor and advise executive managers arises from two sources: reputational capital incentives and compensation incentives. Prior studies have provided evidence that directorships at larger firms are considered more prestigious by directors due to the greater reputational capital associated with these firms (Masulis and Mobbs, 2014). Hence, there is a greater incentive for directors to monitor more effectively when appointed on the boards of these firms. M\&A activities also enhance the reputational capital of NEDs but it is unclear whether NEDs serve their own interests by expanding firm size even if the M\&A is not value enhancing (Masulis and Mobbs, 2012). Our contention is that compensation incentives influence a NED's incentive to monitor

\footnotetext{
${ }^{1}$ The following studies consider the influence of NEDs: Harford (2003); Yermack (2004); Linn and Park (2005); Adams and Ferreira (2008); Zattoni and Cuomo (2010); Masulis and Mobbs (2012); Masulis and Mobbs (2014). The following studies consider the characteristics of NEDs: Vafeas (2003); Balatbat et al. (2004); Gul and Leung (2004); Mura (2007); Christensen et al. (2010); Fahlenbrach et al. (2010); Masulis et al. (2012).
} 
management. ${ }^{2}$ This contention is built on the assumption that the compensation which NEDs receive from different firms drives how they allocate their time and monitoring activities. ${ }^{3} \mathrm{We}$ test our contention in the M\&A context because M\&As represent a significant capital expenditure and are often value decreasing for bidding firm shareholders (e.g., Moeller et al., 2004; Offenburg, 2009; Bugeja and Da Silva Rosa, 2010) indicating that enhanced board monitoring is required at the time of conducting an M\&A.

We study the relation between NEDs' compensation and M\&A activities within the Australian setting for a number of reasons. First, evidence in Bugeja et al. (2014) indicates that the compensation of Australian NEDs is 'economically significant' and that $95 \%$ of firms have an independent director as the Chair of the Board, who on average receives almost twice the average compensation of the other NEDs. The high financial costs of this remuneration are suggestive of firms expecting additional benefits attributed to the greater monitoring and advising ability of NEDs. ${ }^{4}$

Second, in the U.S. the duty of care of executive directors is higher than that for NEDs as the liability of NEDs is not well defined. ${ }^{5}$ However, the Australian Corporations Act 2001 requires that all directors have a strict duty to act in the best interests of the company and to avoid conflicts of interest. ${ }^{6}$ Third, there is a regulatory difference between Australia and the U.S in

\footnotetext{
${ }^{2}$ Although Masulis and Mobbs (2014) consider compensation for NEDs, their study is restricted to the period up to 2006 due to the lack of machine readable data in the U.S. In addition, the compensation data does not include any equity based compensation. Despite this, there is support for NEDs being less inclined to resign from the board when their compensation is higher.

${ }^{3}$ This contention is supported by evidence that NEDs' board meeting attendance increases with their level of compensation (Masulis and Mobbs, 2014).

${ }^{4}$ Our study calculates the average compensation of NEDs on a firm level. The mean of the average NED compensation across firms in our study is $\$ 79,857$, and the average CEO compensation is $\$ 2,104,663$.

${ }^{5}$ Although the U.S. allows NEDs to be prosecuted for certain misconduct (Vasilescu and Russello, 2006), their liability is not well defined. According to Lin, et al. (2011), U.S. firms which provide their executives with higher insurance coverage, tend to be subject to lower takeover announcement abnormal stock returns and pay higher acquisition premiums.

${ }^{6}$ The SEC is only empowered to bring actions under the Federal Securities Law (Securities Act of 1933), which does not cover the fiduciary duties of directors. However, Australian directors can be prosecuted by the Australian Securities and Investments Commission (ASIC) for breaches of fiduciary duty under the Corporations Act 2001.
} 
regards to M\&A completion. Unlike the U.S., under the Australian Corporations Act (s652B) when a takeover is announced the bidder is unable to unilaterally withdraw their tender without the consent of the Australian Securities and Investments Commission. Finally, in the Australian setting the bidder is given the opportunity to increase but not decrease the offer price. These restrictions on the bidding process increase the importance of bidding firm NEDs in Australian takeovers, as their monitoring and advising role is crucial in ensuring that the offer price is not excessive since this initial price cannot subsequently be decreased or withdrawn. ${ }^{7}$

The second motivation for this study is to build on evidence indicating that NEDs' expertise matters. For example, Larcker et al. (2013) suggests that the presence of connected NEDs leads to better corporate performance, and Masulis et al. (2012) find that the presence of foreign NEDs results in better cross-border acquisitions, likely due to their experience in the home region of the target firm. ${ }^{8}$ More recently, Faleye et al. (2014) document that the presence of industry expert NEDs leads to increased firm value and a higher CEO pay-performance sensitivity. Based on these findings we contend that a bidding firm is better able to estimate the underlying value of the target firm when their board includes NEDs with industry expertise in the target firm's industry, which subsequently should reduce the possibility of the firm undertaking a value destroying acquisition. Accordingly, we investigate the association between the industry expertise of bidding firm NEDs and different aspects of M\&A activities.

This study is based on a sample of 272 M\&As between Australian publicly listed companies from the year 2004 to 2011 . We find a significant negative association between NEDs' relative compensation and the bid premium, and a significant positive association between NEDs'

This indicates that in an Australian setting both executives and NEDs are required to be fully informed of the actions of the firm.

${ }^{7}$ The role of target firm NEDs generally and their compensation and industry expertise is an issue that future research may wish to investigate.

${ }^{8}$ However, findings in Khorana et al. (2007) suggest that board industry expertise has no effect on the determinants of mergers within the mutual fund industry. 
relative compensation and the market reaction to $\mathrm{M} \& \mathrm{~A}$ announcements. These results are consistent with the compensation literature and suggest that NEDs are more likely to fulfil their monitoring duties in the presence of greater compensation (Adams and Ferreira, 2008; Zattoni and Cuomo, 2010). In regards to NEDs' industry expertise, we find a negative and significant association with the bid premium and the likelihood of an increase in the offer price. However, we find no association between industry expertise and the market reaction to the takeover announcement. These findings are consistent with the literature that highlights the importance of NED characteristics and/or attributes (Masulis et al., 2012; Larcker et al., 2013). These results are robust to various econometric specifications, variable definitions, different event windows and alternative proxies for NEDs' compensation incentives and industry expertise.

The findings of this study contribute to the growing body of literature on the influence of NEDs' compensation incentives and are of particular interest due to the operation of the 'two strikes' rule on director compensation in Australia. ${ }^{9}$ We provide evidence that higher NEDs' relative compensation results in better outcomes for bidding firm shareholders around an M\&A, which we suggest is via increased monitoring and better advising. Therefore reducing the compensation incentives of NEDs may prove to be value destroying in the long run and this should be taken into consideration when voting on remuneration packages at AGMs.

We also contribute to the literature which examines the importance of NEDs' expertise and experience (Guner et al., 2008, Dass et al., 2013, Faleye et al., 2014). Our results suggest that the industry expertise of NEDs is relevant in an M\&A context as it is associated with lower bid premiums and a lower likelihood of an increased offer price. ${ }^{10}$ Overall, our findings extend the

\footnotetext{
${ }^{9}$ The 'two strikes' rule states that if the executives' and directors' remuneration package is opposed by at least $25 \%$ of votes at two successive annual general meetings (AGMs) then the firm must undergo a board spill. (Corporations Amendment (Improving Accountability on Director and Executive Remuneration Act 2011).

${ }^{10}$ This is consistent with prior literature which indicates that NEDs reduce the likelihood of the completion of value reducing bids (Paul, 2007).
} 
literature on the influence of NEDs' relative compensation and industry expertise to a different corporate context.

The remainder of this paper is structured as follows. Section 2 develops theory and hypotheses on the influence of NEDs' relative compensation and industry expertise. Section 3 details the research design and Section 4 discusses the sample collection and provides descriptive statistics. Sections 5 and 6 include a discussion of the results and additional testing. Finally, Section 7 highlights the limitations of the study and concludes.

\section{Literature Review and hypotheses development}

\subsection{Prior evidence on M\&As}

NEDs have a responsibility to monitor and advise executives as part of their fiduciary duty to shareholders (Fama and Jensen, 1983). It has been argued in prior literature that owners (shareholders) and managers have misaligned incentives; hence NEDs are expected to be objective monitors (Armstrong et al., 2010) and reduce the divergence of interests between shareholders and management (Jensen and Meckling, 1976; Williamson, 1984). As M\&A activities tend to be the largest and most observable form of capital expenditure a firm undertakes, much of the current literature on NEDs examines their influence within an M\&A context. ${ }^{11}$ Furthermore, prior literature indicates that M\&As often result in a loss of shareholder wealth, highlighting the importance of increased attention and monitoring from all directors at the board level, in particular from NEDs. ${ }^{12}$

Although it is expected that the bidding firm's board pays greater attention during the acquisition process, prior research is consistent with many takeovers having excessive bid

\footnotetext{
${ }^{11}$ Cotter et al. (1997); Shleifer and Vishny (1997); Bange and Mazzeo (2004); Moeller et al. (2005); Paul, (2007); Masulis et al. (2007); Bugeja (2009); Masulis and Mobbs (2011); Masulis et al. (2012).

12 Moeller et al. (2004); Moeller et al. (2005); Offenburg (2009); Bugeja and Da Silva Rosa (2010), Harford et al. (2012)
} 
premiums. ${ }^{13}$ Bid premiums may be higher in the presence of hubris on the part of managers (Roll, 1986), as well as entrenched executives on the bidder's board (Masulis et al., 2007; Harford et al., 2012). Excessive bid premiums can also potentially result in a significant wealth transfer from shareholders of the bidder to those of the target firm. Australian evidence emphasises this concern as corporate acquisitions are not associated with improvements in post-acquisition performance, measured using both accrual and cash flow performance indicators (Sharma and Ho, 2002).

Earlier studies have highlighted the importance of NEDs' reputational capital and compensation when deciding whether to undertake an acquisition. ${ }^{14}$ For example, Masulis and Mobbs (2012) demonstrate that despite the association with wealth reduction, NEDs are more inclined to undertake an acquisition to increase their reputational capital. Additionally, results in Deutsch et al. (2007) suggest that the proportion of NEDs' compensation paid as stock increases a firm's acquisition activity.

Prior research has also reported that the initial market reaction to a takeover is an indication of the expected success of the merger, as negative market reactions tend to be associated with unsuccessful acquisitions. ${ }^{15}$ Within both the U.S. and Australian contexts, powerful CEOs have been reported as being more likely to engage in acquisitions in order to increase their compensation, despite the acquisition's association with a negative market reaction (Grinstein and Hribar, 2004; Bugeja et al., 2012). As seen in Certo et al. (2008), NEDs are also likely to support this behaviour and increase their own compensation following an acquisition. Their results indicate that relative to a matched sample, NEDs earn more than twice as much as their

\footnotetext{
${ }^{13}$ Harford (2003); Paul (2007).

${ }^{14}$ Prior literature has indicated the value to shareholders from having NEDs on the board of the target firm. In particular, Cotter et al. (1997) report on the ability of NEDs to identify wealth-reducing acquisitions and make more informed responses to takeover offers.

${ }^{15}$ Luo (2005); Paul (2007); Masulis et al. (2007).
} 
counterparts in the post-acquisition period. Similarly, descriptive evidence in Khorana et al. (2007) suggests that bidding firm directors have a greater positive change in compensation relative to directors in the target firm in across-family mutual fund mergers.

These findings suggest that the decision to undertake a bid in the presence of potential value destruction may be the result of management's self-interest, rather than the interest of shareholders (Harford and $\mathrm{Li}, 2007$ ). Recent evidence also shows that the bidding firm CEO and directors are rewarded with higher future directorships on other boards for the experience attained from an acquisition even if the M\&A reduces shareholder wealth (Harford and Schonlau, 2013). Despite this, the presence and expertise of NEDs has been found to reduce the likelihood of undertaking bad acquisitions. For example, Byrd and Hickman (1992) find that bidders with majority NEDs have higher announcement abnormal returns when compared to those with less than 50\% NEDs, and more recently Masulis et al. (2012) reveal the positive association between M\&A outcomes and the presence of foreign NEDs.

Previous studies have also examined whether directors learn from the announcement reaction when deciding whether to complete or increase the offer price in an acquisition. Upon observing a negative market reaction, NEDs are placed in a position where their motivation to act in the best interest of shareholders and avoid over-paying for a value reducing acquisition are at play. Researchers have reported conflicting evidence on the association between deal completion and the bidding firm market reaction. For example, Paul (2007) suggests that NEDs reduce the possibility of undertaking a value decreasing acquisition within a U.S. setting. However, Bugeja (2009) finds that in an Australian context they make no difference.

Overall, research has highlighted the influence of NEDs' in both the decision to undertake an acquisition as well as the overall outcome. Ultimately, the incentive of NEDs to monitor and advise the board are not limited to reducing the negative effects on shareholder's wealth, but 
are also driven by their own reputational capital and compensation. ${ }^{16}$ Despite this, the effects of NEDs' compensation and industry expertise are yet to be empirically tested within an M\&A context.

\subsection{Hypothesis Development}

Excessive bid premiums are associated with a significant wealth transfer from the bidder to the target firm's shareholders. As NEDs are required to monitor and advise executives, there is an expectation that their presence lowers the probability of the bidder over-paying for the target firm and thus leads to lower bid premiums (Masulis et al, 2007; Paul, 2007). Research also suggests that the presence of self-interested CEOs (Harford and Li, 2007) and/or entrenched inside executives on the board, are usually associated with the payment of higher premiums (Harford, et al. 2012). Following prior findings that NEDs are likely to perform for financial rewards (Adams and Ferreria, 2008; Masulis and Mobbs, 2014), it is expected that greater NED compensation increases their incentive to monitor executives and thus aligns their interests with shareholders. In an M\&A context, we thus expect that higher NED compensation lowers the likelihood that the bidding firm overpays for the target firm.

Previous studies indicate that NEDs' expertise and experience matters. For instance, Guner et al. (2008) find that the presence of financial experts on the board results in increased external financing flows. Goldman et al. (2009) study the influence of political connections and document positive stock returns for firms which have better political connections. More recent studies have examined the influence of the industry expertise of NEDs and find that the presence of industry expert NEDs leads to increased firm value and performance (Faleye et al., 2014; Dass et al., 2013).

\footnotetext{
${ }^{16}$ Sharma and Ho (2002); Grinstein and Hribar (2004); Deutsch et al. (2007); Paul (2007); Bugeja et al. (2012); Masulis and Mobbs (2012).
} 
Building on these findings we argue that bidding firms have greater access to information which can be used to accurately value the target firm when the board includes industry expert NEDs. Furthermore, industry expert NEDs are better placed to monitor the decisions of the CEO to ensure they do not overpay for the target firm. Therefore we predict that:

H1: The takeover bid premium is negatively associated with NEDs' compensation and industry expertise.

Highlighting the value destroying nature of many M\&As, research has provided evidence suggesting that the bidder's market reaction to a takeover announcement is often negative (Masulis et al, 2007; Paul, 2007; Bugeja, 2009). In addition, the market reaction to the takeover announcement is a significant factor in determining the future success of the merger, as findings indicate that deal completion is positively related to the market return around the takeover announcement (Luo, 2005). Although NEDs have been found to have a positive influence on the market reaction to a takeover announcement (Byrd and Hickman, 1992; Masulis et al., 2012), prior research has not examined the influence of the compensation and industry expertise of NEDs. We argue that increased monitoring driven by higher compensation, and a greater ability to monitor and advise due to industry specific knowledge, allows NEDs to make well-informed M\&A decisions which are viewed favourably by the market. Accordingly, it is predicted that:

H2: The market reaction to the bidders' announcement of an $M \& A$ is positively associated with NEDs' compensation and industry expertise.

Following an acquisition announcement, the bidding firm directors observe the markets' reaction to the takeover. If NEDs have shareholders' welfare in mind, this reaction should be an important consideration for subsequent decisions on whether to increase the price or complete the acquisition. As the Australian setting prevents the option to withdraw a takeover, 
this study takes advantage of a test that considers the option to increase the offer price following a negative market reaction, instead of the completion measure used in prior studies (Paul, 2007). It is expected that when NEDs are paid greater compensation or have industry expertise, their enhanced monitoring and advising reduces the likelihood of making a decision to increase the offer price in a value reducing acquisition (Paul, 2007; Masulis et al., 2007). Accordingly, it is predicted that:

H3: The likelihood of an increase in the offer price for an acquisition following a negative market reaction to the takeover announcement, is negatively associated to NEDs' compensation and industry expertise.

We provide evidence on these three hypotheses below.

\section{Research Design and Variable Measurement}

To examine our hypotheses the following ordinary least-squares or logit model is estimated:

Dependent Var. $=\beta_{0}+\beta_{1}$ Compensation $+\beta_{2}$ Industry Expertise

$$
\begin{aligned}
& +\sum \beta_{h} \text { Bidder Characteristics }+\sum \beta_{i} \text { Target Characteristics } \\
& +\sum \beta_{j} \text { Deal Characteristics }{ }_{i}+\sum \beta_{k} \text { Board Characteristics } s_{i}+\varepsilon_{\mathrm{i}}
\end{aligned}
$$

The alternate dependent variables consist of Bid Premium, Cumulative Abnormal Returns $(C A R s)$, and the Change in Offer Price (COP). Bid Premium is defined as the ratio of the final offer price to the target stock price eight weeks prior to the initial merger announcement date minus one. ${ }^{17}$ CARs are measured using three and five day event windows, from days -1 to +1

\footnotetext{
${ }^{17}$ We also test the ratio of initial offer price to target stock price eight weeks prior to the initial merger announcement date minus one, and our conclusions are unchanged.
} 
and -2 to +2 , respectively, where $t=0$ is the takeover announcement day. Abnormal returns are calculated using market adjusted returns. ${ }^{18}$ Finally, COP is defined as an indicator variable equal to one for takeovers in which there was an increase in the offer price following a negative market reaction to the initial takeover announcement. We also partition the sample when examining the change in offer price into positive and negative groups based on the direction of the 3-day CARs.

\subsection{Compensation and Industry Expertise Measures}

The compensation measure used in this study is the average of NEDs' compensation in a firm relative to the CEO's compensation (NED to CEO comp). The size of this measure highlights the relative worth a firm places on NEDs compared to the CEO; with a lower measure arguably suggesting that the CEO has greater importance or power relative to the NEDs. ${ }^{19}$

We use a measure of industry expertise similar to that in Khorana et al. (2007) that allows for a test of whether current NEDs' industry expertise influences M\&A activities. This measure is an indicator variable (Ind. Expert NEDs) coded as one if any NED on the bidding firm board holds a current directorship on a board that is in the same industry as the target firm. For within industry acquisitions, the NED must hold a board seat in the same industry as the target firm other than the current seat on the acquiring firm's board. ${ }^{20}$ In measuring expertise (of CEOs or directors) prior studies have based their measure upon 2-digit SIC (Cohen et al. 2014), 4-digit SIC (Dass et al., 2014), or Fama-French 12-industries (Custódio and Metzger, 2013). We wish

\footnotetext{
18 Thinly traded stocks are dealt with using the 'lumped' method outlined in Kallunki (1997) and Maynes and Rumsey (1993), where non-trading days are assigned a zero return.

${ }^{19}$ We test the robustness of our results to our alternative measures of NED compensation in Section 6.

${ }^{20}$ All NEDs would be coded as experts for intra-industry acquisitions and thus an additional board seat in the same industry as the target firm signifies greater expertise. We test the sensitivity of this measure by including an indicator variable for intra-industry acquisitions in our tests, which does not alter our results.
} 
to limit the potential noise in our measure and hence calculate our expertise variable using 6digit GICS codes.

\subsection{Control variables}

In addition to the key variables, a set of controls based on prior M\&A research are included in the models. ${ }^{21}$ Financial controls are measured at the end of the financial year prior to the takeover announcement. We employ two-way clustering to control for year and industry effects. Industry is based on the 2-digit GICS code of the target firm. ${ }^{22}$

\subsubsection{Bidder Controls}

The bidder firm characteristics included as controls are: the firm's leverage, market-to-book ratio and free cash flow. Leverage is included as a control (Leverage) as it is expected to relate to the future free cash flow of the firm (Masulis et al., 2007) and higher leverage tends to deter management from undertaking value reducing acquisitions (Humphery-Jenner and Powell, 2011). Leverage is measured as the ratio of total debt to total assets for the bidding firm as at the balance date in the year prior to the acquisition.

The market-to-book ratio (Market to Book) is included to control for the use of overvalued equity in an acquisition (Masulis et al., 2007). This variable is measured as the ratio of market capitalisation to the book value of equity of the bidding firm at the balance date in the year prior to the acquisition. Finally, free cash flow (Bidder_FCF) is included as a control for the theorised agency costs of free cash flow (Jensen 1986) which suggests that management may invest in less productive assets (e.g. Dittmar and Mahrt-Smith, 2007). Free cash flow is

\footnotetext{
${ }^{21}$ See Cotter et al. (1997); Harford (2003); Moeller et al. (2004); Masulis et al. (2007); Paul (2007); Harford et al. (2012).

${ }^{22}$ We also estimate our models including year and industry indicator variables for robustness and the results are unchanged.
} 
measured as the difference between the cash flow from operations and cash flow from investments scaled by total assets in the year prior to the acquisition.

\subsubsection{Target Controls}

The target firm characteristics included as controls are firm performance and free cash flow. As indicated in Jensen (1986), firms are more likely to have agency problems in the presence of free cash flow. Therefore, we control for the difference between cash flow from operations and cash flow from investments scaled by total assets for the target firm, for the year prior to the acquisition (Target_FCF). It is expected that the greater the FCF of the target, the more the bidder is required to pay.

Masulis et al. (2007) highlights the need to control for better recent target firm performance. Accordingly, we include the ratio of net profit to total assets for the target firm $(R O A)$, for the year prior to the acquisition. It is expected that a well performing target firm requires an offer with a higher premium in order for directors to recommend offer acceptance. Additionally, a positive market reaction is expected for profitable target firms as these acquisitions are more likely to further improve firm performance post-acquisition.

\subsubsection{Deal Controls}

Consistent with prior M\&A literature we utilise deal characteristic controls including: takeover hostility, toehold, method of payment, relative size, and whether multiple firms are competing for the same target firm. We control for hostile takeovers due to their association with higher premiums and lower CARs (Humphery-Jenner and Powell, 2011). These acquisitions are identified using an indicator variable taking the value of one if the initial recommendation by the target firm board (as per the takeover statements) is to reject the takeover offer, and zero otherwise (Hostile). Masulis et al. (2007) indicate that the method of payment has implications 
for shareholder gains, with equity financed acquisitions resulting in the lowest gains. The method of payment is controlled for using a binary variable (AllCash) equal to one if the acquirer makes a pure cash offer and zero otherwise.

Relative deal size is controlled for using the ratio of the target to bidding firm's market capitalisation (Relative Size). Relative size is expected to be negatively associated with CARs (Masulis et al., 2007; Paul, 2007) as a larger target firm has greater comparative bargaining power resulting higher bid premiums and a greater frequency of revisions in the offer price. A higher toehold is expected to reduce the takeover premium as the quantity of shares to be purchased is reduced (Stulz, 1988; Stulz et al., 1990). Toehold is measured as the percentage share ownership of the bidding firm in the target firm at the date of the announcement of the acquisition (Toehold).

Further, as premiums are expected to be higher in the presence of competing bids an indicator variable is included for the presence of multiple bidders for the same target. The variable takes a value of one to indicate the presence of multiple bids for the same firm within a six month period of the takeover announcement (Competing), and zero otherwise. Competing takeovers may be viewed unfavourably by the market due to the potential for excessive bid premiums (Paul, 2007). Competing is therefore predicted to be positively associated with the bid premium and $C O P$ and have a negative association with CARs.

\subsubsection{Bidder Board Controls}

As previously indicated, high agency costs and information asymmetry for bidding firms are expected at the time of an M\&A; hence the monitoring function of the firm's board is of importance in such a setting. In particular, the size and composition of the bidding board is expected to have an impact on the effectiveness of the board's monitoring. Board size is controlled for as larger boards tend to be associated with lower monitoring of management 
(Linck et al., 2008) and hence compromised shareholder interests. Additionally, Moeller et al. (2004) find that bidders with larger boards pay higher premiums. Board size is measured as the number of directors on the board at the date of the acquisition (Board Size).

As the presence of NEDs is expected to decrease the probability of undertaking a valuedecreasing acquisition (Masulis et al., 2007), a control is included for the percentage of NEDs on the bidding board (NED). This is measured as the ratio of the number of NEDs to total board size prior to the takeover announcement. It is expected that the association with bid premium and COP is negative, whilst having a positive association with CARs.

In addition, we control for bidding firm director ownership as prior literature indicates that it is positively aligned with shareholder wealth, and therefore has an impact on the directors' decision to undertake a value decreasing acquisition (Fich and Shivdasani, 2005). Director ownership is measured as the aggregate percentage ownership of the bidding firm directors at the announcement of the acquisition (Dir. Ownership).

\section{Sample and Data}

\subsection{Sample}

An initial sample of 688 takeovers of Australian publicly listed companies between the years 2004 and 2011 is identified from the Connect 4 Mergers and Acquisitions database. All financial statement information to calculate the bidder and target variables are hand collected from the annual reports for the financial year preceding the acquisition announcement date. M\&A data for control variables and the offer price for calculating bid premiums were hand collected from the takeover statements provided on the Connect 4 Mergers and Acquisitions database. NEDs' compensation for the bidding firm was downloaded from the Connect 4 Boardroom database for the year prior to the acquisition, with director level data for 120 missing firm observations being hand collected from the respective annual reports. NEDs' 
compensation for other directorships (i.e., non-bidding firms) were matched based on NED name and was limited to those directorships found within the Connect 4 Boardroom database.

Directorships of bidding firm directors on other ASX firms was used to measure industry expertise for bidding firm NEDs and were also matched based on name within the Connect 4 Boardroom database for the year of the acquisition. Any missing data for the director expertise observations are hand collected, where available, from the disclosure of other directorships in the annual reports, as well as disclosures reported in the Morningstar DatAnalysis Premium database. Returns data were extracted from the SIRCA Limited and DataStream databases with data for 130 missing observations being individually downloaded from Morningstar DatAnalysis Premium.

To be included in the final sample both the target and bidding firm must be Australian listed companies. Exclusions include 27 observations for which the date of acquisition toehold was greater than $50 \%$, as this suggested the bidder was compulsorily acquiring the remaining shares. Serial acquirers were also excluded as these firms are likely different from the average bidding firm engaging in an M\&A (resulting in the removal of 46 observations). Serial acquirers are defined as firms which engage in two or more acquisitions within the same calendar year. The final usable sample consisted of $272 \mathrm{M} \& A s .^{23}$ Due to the limited number of observations for which NEDs' compensation data are available, the final number of observations used in each test varies. Initially we test the NEDs' relative compensation and industry expertise separately, for which the sample for industry expertise consists of the majority of the 272 observations. ${ }^{24}$ A breakdown of the sample selection process is provided in Panel A of Table 1.

\footnotetext{
${ }^{23}$ Our sample includes successful (185) and unsuccessful (87) M\&As (of which 44 were withdrawn).

24 The results of these and additional tests are discussed in Section 6.
} 


\section{(Insert Table 1 about here)}

Panel B of Table 1 provides a distribution of firms by calendar year. The sample is not concentrated in any particular year, with the lowest frequency in $2011(7.72 \%)$ and the highest in $2007(18.38 \%)$. Panel C of Table 1 reports the annual frequency of takeovers based on target firm two digit GICS classification. The Materials industry comprises the greatest proportion of firms within the sample $(30.15 \%)$. The industry with the lowest representation is Utilities $(0.37 \%)$, followed by Telecommunications (3.31\%).

\subsection{Descriptive Statistics}

Table 2 reports the descriptive statistics for the total sample, with compensation measures and bidder and target firm controls being winsorised at the 5\% level.

\section{(Insert Table 2 about here)}

Panel shows that the median Bid Premium is $25 \%$; the mean is $71.7 \%$, and the mean 3 -day and 5-day $C A R$ are $0.6 \%$ and $9.6 \%$, respectively. These levels are consistent with those in prior literature (Masulis et al., 2007; Harford et al, 2012). There is a change in offer price (COP) in 9.6\% of the sample, with the positive and negative partitions suggesting that on average a slightly greater likelihood of the offer price increasing within the positive partition. Panel B presents the statistics for the key test variables. The average NED to CEO comp is $7.74 \%$, whilst $30.9 \%$ of the boards have at least one industry expert. ${ }^{26}$

\footnotetext{
${ }^{25}$ We perform a robustness test of bid premium by excluding observations with a value in the highest and lowest $5 \%$ of the sample, discussed in section 6 .

${ }^{26}$ The mean of the average level of NED compensation in firms in our sample is $\$ 79,857$. The mean of the average level of total compensation received from by a firm's NEDs from their portfolio of directorships is $\$ 113,469$. Note, because our data reports the mean compensation for NEDs within a firm, Table 2 effectively displays the mean of the average value of these variables across firms.
} 
Panel C reports the descriptive statistics for the control variables. The average Market to Book of the bidding firm is 2.79 and the Relative Size measure indicates that on average the target firm's market capitalisation is $57 \%$ of that for the bidding firm. On average the bidding firm has approximately seven directors on their board, with $75 \%$ of the board being comprised of NEDs. This is similar to the board composition in Harford et al. (2012). Overall, the values for the descriptive statistics are consistent with prior literature.

Table 3 displays the correlation matrix for all the variables.

\section{(Insert Table 3 about here)}

The largest correlation which exists between variables within the same regression is that between Toehold and All Cash (-0.38). Therefore there does not appear to be any multicollinearity concerns with the estimation of the regression models. ${ }^{27}$ The correlations between the compensation measure and the dependent variables are in the predicted directions with correlations ranging between -0.13 and 0.11 , however the COP total and negative partitions are insignificant. Furthermore, the correlations between industry expertise and the dependent variables are also as predicted (bid premium (-0.077), COP (-0.055), and CAR (0.002)), however all associations are insignificant.

\footnotetext{
${ }^{27}$ In order to confirm this, VIF diagnostic testing were conducted for all regressions and this confirmed no significant multicollinearity was present.
} 


\section{Results}

\subsection{Results for Hypothesis 1}

Table 4 reports the results of the OLS regression for the association between NED compensation and industry expertise and the size of the bid premium. ${ }^{28}$

\section{(Insert Table 4 about here)}

The R-squared of the OLS regressions is $7.02 \%$, with an F-statistic of 2.00 indicating that the regression is significant. The compensation variable of interest is NED to CEO comp, which is significant at the $10 \%$ level. This finding indicates that higher compensation of NEDs is associated with lower takeover premiums and is consistent with the results in Adams and Ferreira (2008) who show that NEDs perform for financial rewards. Industry Expert NEDs is also negative and significant (-0.187) at the $10 \%$ level, consistent with our predictions. Overall these findings suggests that on average the relative compensation of NEDs and the presence of one or more NED industry expert / experts is significant in influencing their monitoring role to the board. The control variables which are significant are Market to Book $(0.029, \mathrm{p}<0.05)$ and Competing $(-0.232, \mathrm{p}<0.10)$. Of note, the Relative Size of the acquisition is insignificant, inconsistent with the findings in Humphery-Jenner and Powell (2011). Also, Target_FCF and Bidder_FCF are not significantly associated with bid premiums. In summary, the results provide weak support for $\mathrm{H} 1$ with a negative association between NEDs relative compensation and industry expertise and takeover premiums.

\footnotetext{
${ }^{28}$ In order to check for the presence of heteroskedasticity the White (1980) and Breusch-Pagan (1979) tests were conducted. Results indicated that there was no evidence to reject the presence of homoskedasticity.
} 


\subsection{Results for Hypothesis 2}

Table 5 reports the results of the OLS regression for the association between compensation and industry expertise and the market reaction to the takeover announcement. The results in column (1) consider the 3-day CAR, and column (2) considers the 5-day CAR.

\section{(Insert Table 5 about here)}

The R-squared of the OLS regression is $9.12 \%$ and $13.30 \%$, with F-statistics of 4.02 and 7.82, respectively indicating that both regressions are significant at the $1 \%$ level. The coefficient for NED to CEO comp in column (1) is significant at the $10 \%$ level, and significant at the $1 \%$ level in column (2). These findings are as predicted and consistent with those in Byrd and Hickman (1992) and Masulis et al. (2012), who find that NEDs have a positive influence on the market reaction to takeover announcements. However, the findings in this paper extend these results by indicating the influence of NEDs is likely to be a result of the relative level of their compensation. Across columns (1) and (2) the coefficient on Industry Expert NEDs is insignificant.

The only control variable that is significant across both columns is Dir. Ownership. $(-0.002$, $\mathrm{p}<0.05$ and $-0.002, \mathrm{p}<0.01$ ), suggesting that in the presence of higher director shareholdings the market reaction to the takeover is negative, inconsistent with predictions. The Relative Size of the acquisition has no association with the market reaction, consistent with the findings in Harford et al (2012), but inconsistent with Masulis et al. (2007). Column (2) reports Competing is positively associated with the market reaction to the takeover announcement, inconsistent with expectations (Paul, 2007). One possible explanation is that when there is competing bidders for a target firm this signals greater possible performance improvements postacquisition. Finally, the proportion of NEDs on the board $(N E D)$ is also significantly negative 
in column (2), suggesting that the market may view acquisitions by boards dominated by insiders as more value enhancing. In summary, the results provide partial support for $\mathrm{H} 2$ with higher NEDs' relative compensation found to be positively associated with bidding firm CARs. However, the results show that industry expertise is not related to announcement returns.

\subsection{Results for Hypothesis 3}

Table 6 reports the results of the logit regression examining the association between compensation and industry expertise and an increase in the offer price. Column (1) reports the results of the logit regression for the change in offer price for the total sample. Columns (2) and (3) report the results after partitioning the sample into positive and negative groups based on the sign of the market reaction around the takeover announcement.

\section{(Insert Table 6 about here)}

The Pseudo R-squared ranges from 37.69 to $43.95 \%$ and the Chi-square statistic ranges from 62.06 to 66.76 indicating that the regressions are significant at the $1 \%$ level. Across all columns the coefficient for NED to CEO comp is insignificant. Looking at Industry Expert NEDs, the coefficients in columns (1) and (3) are negative and significant at the $1 \%$ level (-2.821) and 5\% level (-3.611), respectively. However, there is no relation between industry expertise and an increase in offer price when the announcement return is positive (column 2). These results suggest that the advice of industry expert NEDs is important in the decision on whether to increase the offer price, and that industry expert NEDs recognise the signal from the negative announcement return. 3-day CARs have a negative association with the decision to revise the offer price for the complete sample in column (1) but a positive and significant association in column (2). This suggests that bidding firms learn from the announcement reaction when deciding whether to increase the offer price. 
Of the control variables, the proportion of NEDs on the board (NED) is negative and significant in column (1) consistent with NEDs providing a monitoring and advising role to protect shareholder value. All Cash, Relative Size, and Board Size are also negative and significant in column (1). In column (2) Bidder_FCF is negatively associated with the likelihood of an increase in offer price, which is inconsistent with expectations. However, $R O A$ is positive and significant as expected, indicating that bidder firms are more likely to increase their offer price for better performing targets when there is a positive market reaction to the bid. Hostile and Toehold are also positively associated with the change in offer price in column (2) suggesting that firms intent on obtaining a controlling position are more likely to increase their offer price when the M\&A is viewed positively by the market. Competing is also positive and significant in column (2). Finally Dir. Ownership is positive and significant across all columns, inconsistent with expectations.

In summary, the results provide partial support for H3. Relative NEDs' compensation is not associated with the likelihood of an increase in the offer price. However, firms with industry expert NEDs are less likely to increase the offer price, which appears driven by acquisitions with negative announcement returns.

\section{Additional Tests}

A number of additional tests are performed to test the robustness of our results. First, we test NEDs' relative compensation and industry expertise after including the 46 serial acquirers back into our sample. While our results on NEDs' relative compensation remain largely unchanged, the results on NEDs' industry expertise are no longer significant using a variety of measures to define industry expertise, including: 4 and 6-digit GICS indicator variables and percentages of NEDs that are experts, total industry boards held by NEDs which is defined as the total number 
of boards held by NEDs in the same industry as the target firm scaled by the total number of NEDs in the acquiring firm; and including in the regression an indicator variable if the target firm and the acquiring firm are in the same industry. Second, we test NEDs' relative compensation and industry expertise separately and the results remain unchanged. Third, we re-estimated our models after including an indicator variable equal to one if the acquisition is intra-industry and zero if it is diversified (using 6 digit GICS). 148 acquisitions are within the same industry. Including this control does not change our results and the additional control is insignificant across all tests.

Fourth, we considered alternative proxies for NEDs' relative compensation including: the ratio of the highest paid NEDs' compensation to the CEO's compensation; the ratio of the nonexecutive Chairperson's compensation to the CEO's compensation, and the ratio of total NEDs' compensation to the CEO's compensation. The findings are consistent for these alternative measures. Fifth, NEDs may have a greater incentive to monitor on the board that represents their biggest or most prestigious directorship. Therefore, we tested NEDs' total compensation received from the bidding firm as a ratio of the compensation that NEDs receive from all their directorships. This aggregate portfolio measure is insignificant when replacing our main measure of NEDs' relative compensation as well as when it is included as an additional variable. We also test the average number of other board seats, tenure and age of the NEDs. The expectation being that the 'busier', closer to retirement, or long tenured NEDs which may have been 'captured' by management, perform lower quality monitoring. All three of these additional variables are insignificant in our additional tests.

Sixth, we re-estimate our models using robust regressions and our results remain largely unchanged. Seventh, we removed 16 observations from the sample in which bidding NEDs own greater than $5 \%$ of their firm's shares and our results remained unchanged. Eighth, we removed 19 observations from the sample in which the bid premium fell within the highest or 
lowest $5 \%$ of values. Doing so resulted in NEDs' relative compensation being significant at the $1 \%$ level and NED industry experts being significant at the $5 \%$ level in the tests of Hypothesis One. Last, Moeller et al. (2005) document that between 1998 and 2001, a small number of highly valued firms made value destroying acquisitions which drove negative returns on acquisition announcements. Therefore, we partitioned the sample based on the median market-to-book $(M T B)$ of bidding firms. The sign and significance of our results for the bid premium remains unchanged for low MTB firms, but the test variables for 3- and 5-day CARs are insignificant. However, for large MTB firms the NED to CEO compensation variable is insignificant in the bid premium test but positive and significant (at the 5 and $1 \%$ level) for 3- and 5-day CARs. These results are counter to the argument that large MTB firms are making value destroying acquisitions.

\section{Conclusion}

This study examines the effects of NEDs' relative compensation and industry expertise in the context of M\&As. Based on a sample of 272 acquisitions between Australian listed companies for the period between 2004-2011 we find that higher NEDs' relative compensation is significant in reducing the bid premium and results in higher bidding firm CARs. However, there is no association between relative NEDs' compensation and changes in offer price. We also find that NEDs' industry expertise is associated with lower bid premiums and less likelihood of increasing the offer price, which is stronger when the announcement return is negative. However, there is no association between NEDs' industry expertise and announcement returns. These results are robust to a number of sensitivity tests. Overall, our findings provide support for recent studies which examine different effects of NEDs' compensation and industry expertise. 
These findings are subject to a number of limitations. First, the sample is limited to the acquisitions reported within the Connect4 Mergers and Acquisitions database, and to those in which the bidder and the target are Australian listed companies. Researchers may wish to examine if these results hold within other institutional settings. Second, we excluded firms that held more than $50 \%$ of the target firm's shares and firms that engaged in multiple acquisitions within the year. Hence, our results are not generalizable to this small minority of firms. Third, the influence of any external acquisition advice to the firm is outside the scope of this study. It may also be worthwhile for future research to examine the impact of target firm NEDs' relative compensation on the decisions made by the target firm's board. 


\section{References}

Adams R and Ferreira D (2008) Do directors perform for pay? Journal of Accounting and Economics 46: 154-171.

Alchian A and Demsetz H (1972) Production, information costs, and economic organization. The American Economic Review 62: 777-795.

Armstrong C, Guay W and Weber J (2010) The role of information and financial reporting in corporate governance and debt contracting. Journal of Accounting and Economics 50: 179-234.

Asquith P (1983) Merger bids, uncertainty, and stockholder returns. Journal of Financial Economics 11: 51-83.

Balatbat M, Taylor, S and Walter T (2004) Corporate governance, insider ownership and operating performance of Australian initial public offerings. Accounting and Finance 44: 299-328.

Bange M and Mazzeo M (2004), Board Composition, Board Effectiveness, and the Observed Form of Takeover Bids. Review of Financial Studies 17: 1185-1215.

Breusch T and Pagan A (1979) A simple test for heteroscedasticity and random coefficient variation. Econometrica 47: 1287-1294.

Bugeja M (2009) Monitoring and The Acquiring Firm Reaction to Bad Takeover Bids. Corporate Ownership and Control 7: 208-223.

Bugeja M and Da Silva Rosa R (2010) Capital gains taxation and shareholder wealth in takeovers. Accounting and Finance 50: 241-262.

Bugeja M, Da Silva Rosa R, Duong L and Izan H (2012) CEO Compensation from M\&As in Australia. Journal of Business Finance \& Accounting 39: 1298-1329.

Bugeja M, Fohn S and Matolcsy Z (2014) The Determinants of the Levels and Changes of Non-Executive Director Compensation. Accounting and Finance, forthcoming.

Byrd J and Hickman K (1992) Do outside directors monitor managers?: Evidence from tender offer bids. Journal of Financial Economics 32: 195-221.

Certo S, Dalton C, Dalton D and Lester R (2008) Boards of Directors' Self Interest: Expanding for Pay in Corporate Acquisitions? Journal of Business Ethics 77: 219-230.

Christensen J, Kent P and Stewart J (2010) Corporate Governance and Company Performance in Australia J. Christensen, P. Kent and J. Stewart Corporate Governance and Company Performance in Australia. Australian Accounting Review 20: 372-386. 
Cohen, J. R., U. Hoitash, G. Krishnamoorthy, and A. M. Wright. 2014. The Effect of Audit Committee Industry Expertise on Monitoring the Financial Reporting Process. Accounting Review 89 (1):243-273.

Cotter J, Shivdasani A and Zenner M (1997) Do independent directors enhance target shareholder wealth during tender offers? Journal of Financial Economics 43: 195-218.

Custodio C and Metzger D (2013) How do CEOs Matter? The effect of industry expertise on acquisition returns, The Review of Financial Studies 26: 2008-2047.

Dass, N., O. Kini, V. Nanda, B. Onal, and J. Wang. 2014. Board Expertise: Do Directors from Related Industries Help Bridge the Information Gap? Review of Financial Studies 27 (5):1533-1592.

Deutsch Y, Keil T and Laamanen T (2007) Decision Making in Acquisitions: The Effect of Outside Directors' Compensation on Acquisition Patterns, Journal of Management 33: $30-56$.

Dittmar A and Mahrt-Smith J. (2007). Corporate governance and the value of cash holdings. Journal of Financial Economics 83: 599-634.

Dodd P (1980) Merger proposals, management discretion and stockholder wealth. Journal of Financial Economics 8: 105-137.

Fahlenbrach R, Low A and Stulz R (2010) The dark side of outside directors: Do they quit when they are most needed? National Bureau of Economic Research, working paper.

Faleye O, Hoitash R and Hoitash U (2014) Industry expertise on corporate boards. Northeastern University, working paper.

Fama E and Jensen M (1983) Separation of Ownership and Control Journal of Law and Economics 26: 301-325.

Fich E and Shivdasani A (2005) The impact of stock-option compensation for outside directors on firm value. Journal of Business 78: 2229-2254.

Goldman E, Rocholl J and So J (2009) Do politically connected boards affect firm value? The Review of Financial Studies 22: 2331-2360.

Gray S and Nowland J (2013) Is prior director experience valuable? Accounting and Finance 53: 643-666.

Grinstein Y and Hribar P (2004) CEO compensation and incentives: Evidence from M\&A bonuses. Journal of Financial Economics 73: 119-143.

Gul F and Leung S (2004) Board leadership, outside directors' expertise and voluntary corporate disclosures. Journal of Accounting and Public Policy 23: 351-379. 
Guner, A., Malmendier, U., and Tate, G, 2008, 'Financial expertise of directors', Journal of Financial Economics, vol. 88, no. 2. pp. 323-354.

Harford J (2003) Takeover bids and target directors' incentives: the impact of a bid on directors' wealth and board seats. Journal of Financial Economics 69: 51-83.

Harford J, Humphery-Jenner M and Powell, R (2012) The sources of value destruction in acquisitions by entrenched managers. Journal of Financial Economics 106: 247-261.

Harford J and Li K (2007) Decoupling CEO Wealth and Firm Performance: The Case of Acquiring CEOs. The Journal of Finance 62: 917-949.

Harford J and Schonlau R (2013) Does the director labor market offer ex post settling-up for CEOs? The case of acquisitions. Journal of Financial Economics 110: 18-36.

Humphery-Jenner M and Powell R (2011) Firm size, takeover profitability, and the effectiveness of the market for corporate control: Does the absence of anti-takeover provisions make a difference? Journal of Corporate Finance 17: 418-437.

Jensen M (1986) Agency Cost Of Free Cash Flow, Corporate Finance, and Takeovers. American Economic Review 76: 323-329.

Jensen M and Meckling W (1976) Theory of the firm: Managerial behavior, agency costs and ownership structure. Journal of Financial Economics 3: 305-360.

Kallunki J (1997) Handling missing prices in a thinly traded stock market: implications for the specification of event study methods. European Journal of Operational Research 103: 186-197.

Khorana A, Tufano P and Wedge L (2007) Board structure, mergers, and shareholder wealth: A study of the mutual fund industry. Journal of Financial Economics 85: 571-598.

Larcker D, So E and Wang C (2013) Boardroom centrality and firm performance. Journal of Accounting and Economics 55: 225-250.

Lin C, Officer M and Zou H (2011) Directors' and officers' liability insurance and acquisition outcomes. Journal of Financial Economics 102: 507-525.

Linck J, Netter J and Yang T (2008) The determinants of board structure. Journal of Financial Economics 87: 308-328.

Linn S and Park D (2005) Outside director compensation policy and the investment opportunity set. Journal of Corporate Finance 11: 680-715.

Luo Y (2005) Do Insiders Learn from Outsiders? Evidence from Mergers and Acquisitions. The Journal of Finance 60: 1951-1982. 
Masulis R and Mobbs S (2011) Are All Inside Directors the Same? Evidence from the External Directorship Market. The Journal of Finance 66: 823-872.

Masulis R and Mobbs S (2012) The Consequences of Independent Director Reputation Incentives on Board Decision Making and Firm Actions. University of New South Wales, Working Paper.

Masulis R and Mobbs S (2014) Independent director incentives: Where do talented directors spend their limited time and energy? Journal of Financial Economics 111: 406-429.

Masulis R, Wang C and Xie,F. (2012) Globalizing the boardroom-The effects of foreign directors on corporate governance and firm performance. Journal of Accounting and Economics 53: 527-554.

Masulis R, Wang C and Xie F (2007) Corporate Governance and Acquirer Returns. The Journal of Finance 62: 1851-1889.

Maynes E and Rumsey J (1993) Conducting event studies with thinly traded stocks. Journal of Banking and Finance 17: 145-57.

Moeller S, Schlingemann F and Stulz R (2004) Firm size and the gains from acquisitions. Journal of Financial Economics 73: 201-228.

Moeller S, Schlingemann F and Stulz R (2005) Wealth Destruction on a Massive Scale? A Study of Acquiring-Firm Returns in the Recent Merger Wave. The Journal of Finance 60: 757-782.

Mura R (2007) Firm Performance: Do Non-Executive Directors Have Minds of their Own? Evidence from UK Panel Data. Financial Management 36: 81-112.

Offenburg D (2009) Firm size and the effectiveness of the market for corporate control. Journal of Corporate Finance 15: 66-79.

Paul D (2007) Board Composition and Corrective Action: Evidence from Corporate Responses to Bad Acquisition Bids. Journal of Financial and Quantitative Analysis 42: 759-783.

Roll R (1986) The Hubris Hypothesis of Corporate Takeovers. The Journal of Business 59: 197-216.

Sharma D and Ho J. (2002) The Impact of Acquisitions on Operating Performance: Some Australian Evidence. Journal of Business Finance \& Accounting 29: 155-200.

Shleifer A and Vishny R (1997) A Survey of Corporate Governance. The Journal of Finance 52: $737-783$.

Stulz R (1988) Managerial control of voting rights: financing policies and the market forcorporate control. Journal of Financial Economics 20: 25-54. 
Stulz R, Walkling R and Song M (1990) The distribution of target ownership and the division of gains in successful takeovers. The Journal of Finance 45: 817-833.

Vafeas N (2003) Length of Board Tenure and Outside Director Independence. Journal of Business Finance \& Accounting 30: 1043-1064.

Vasilescu A and Russello G (2006) As gatekeepers, independent directors of public companies face additional scrutiny and liability in the post-Enron/WorldCom world. International Journal of Disclosure and Governance 3: 3-15.

White H (1980) A heteroskedasticity-consistent covariance matrix estimator and a direct test for heteroskedasticity. Econometrica 48: 817-838.

Williamson O (1984) Corporate Governance. The Yale Law Journal 93:1197-1230.

Yermack D (2004) Remuneration, Retention, and Reputation Incentives for Outside Directors. The Journal of Finance 59: 2281-308.

Zattoni A and Cuomo F 2010, How Independent, Competent and Incentivized Should Nonexecutive Directors Be? An Empirical Investigation of Good Governance Codes. British Journal of Management 21: 63-79. 


\section{Table 1 - Sample Construction}

\section{Panel A: Sample Selection}

Acquisition bids in the Connect 4 database

688

Deletions:

Unlisted Bidders 345

Toehold $>50 \%$

Serial Acquirers

Total usable M\&A observations

Panel B: Frequency of takeovers by year

\begin{tabular}{lcccc} 
Calendar year & Frequency & Cumulative Freq. & Per cent (\%) & Cumulative \% \\
\hline 2004 & 27 & 27 & 9.93 & 9.93 \\
2005 & 25 & 52 & 9.19 & 19.12 \\
2006 & 39 & 91 & 14.34 & 33.46 \\
2007 & 50 & 141 & 18.38 & 51.84 \\
2008 & 39 & 180 & 14.34 & 66.18 \\
2009 & 41 & 221 & 15.07 & 81.25 \\
2010 & 30 & 251 & 11.03 & 92.28 \\
2011 & 21 & 272 & 7.72 & 100 \\
\hline
\end{tabular}

Panel C: Frequency of takeovers by year and target firm industry

\begin{tabular}{|c|c|c|c|c|c|c|c|c|c|c|c|}
\hline $\begin{array}{l}\text { Industry } \\
\text { (Two digit GICS) }\end{array}$ & Energy & Materials & Industrials & $\begin{array}{l}\text { Cons. } \\
\text { Disc. }\end{array}$ & $\begin{array}{l}\text { Cons. } \\
\text { staples }\end{array}$ & $\begin{array}{l}\text { Health } \\
\text { Care }\end{array}$ & Financials & I.T. & Telcom. & Utilities & Total \\
\hline 2004 & - & 5 & - & 6 & 2 & 4 & 7 & 3 & - & - & 27 \\
\hline 2005 & 2 & 4 & 4 & 5 & 4 & 2 & 1 & 2 & 1 & - & 25 \\
\hline 2006 & 7 & 10 & 3 & 4 & - & 2 & 8 & 3 & 1 & 1 & 39 \\
\hline 2007 & 4 & 16 & 5 & 8 & - & 4 & 8 & 2 & 3 & - & 50 \\
\hline 2008 & 9 & 11 & 3 & 1 & 1 & 1 & 9 & 2 & 2 & - & 39 \\
\hline 2009 & 8 & 16 & 4 & 3 & - & 1 & 6 & 2 & 1 & - & 41 \\
\hline 2010 & 5 & 12 & 5 & 1 & 1 & - & 4 & 1 & 1 & - & 30 \\
\hline 2011 & 4 & 8 & - & 1 & - & - & 7 & - & - & - & 21 \\
\hline Total & 39 & 82 & 24 & 29 & 8 & 14 & 50 & 16 & 9 & 1 & 272 \\
\hline$(\%)$ & 14.34 & 30.15 & 8.82 & 10.66 & 2.94 & 5.15 & 18.38 & 5.88 & 3.31 & 0.37 & 100 \\
\hline
\end{tabular}




\begin{tabular}{|c|c|c|c|c|c|c|}
\hline Variable & $\mathrm{N}$ & Mean & Median & Std. Dev. & Min & $\operatorname{Max}$ \\
\hline \multicolumn{7}{|l|}{ Panel A-Dependent Variables } \\
\hline Bid Premium & 270 & 0.717 & 0.250 & 2.498 & -0.978 & 31.500 \\
\hline Log(Bid Premium +1) & 270 & 0.224 & 0.223 & 0.767 & -3.807 & 3.481 \\
\hline $\mathrm{CAR}_{(-1,+1)}$ & 272 & 0.006 & -0.001 & 0.087 & -0.260 & 0.422 \\
\hline $\operatorname{CAR}_{(.2,+2)}$ & 242 & 0.013 & 0.004 & 0.106 & -0.272 & 0.481 \\
\hline COP ${ }_{\text {Total }}$ (Indicator) & 272 & 0.096 & 0 & 0.295 & 0 & 1 \\
\hline COP Positive (Indicator) & 272 & 0.099 & 0 & 0.300 & 0 & 1 \\
\hline COP Negative (Indicator) & 272 & 0.096 & 0 & 0.295 & 0 & 1 \\
\hline \multicolumn{7}{|l|}{ Panel B-Test Variables } \\
\hline NED to CEO comp. (\%) & 181 & 7.743 & 5.702 & 5.770 & 1.912 & 22.277 \\
\hline Industry Expert NEDs (Indicator) & 272 & 0.309 & 0 & 0.463 & 0 & 1 \\
\hline \multicolumn{7}{|l|}{ Panel C-Control Variables } \\
\hline Leverage & 272 & 0.430 & 0.455 & 0.262 & 0.028 & 0.942 \\
\hline Market to Book & 272 & 2.788 & 1.991 & 2.311 & 0.267 & 8.532 \\
\hline Bidder_FCF & 272 & 0.137 & 0.147 & 0.239 & -0.423 & 0.549 \\
\hline Target_FCF & 271 & 0.128 & 0.117 & 0.243 & -0.423 & 0.560 \\
\hline ROA & 271 & -0.107 & 0.009 & 0.298 & -0.968 & 0.190 \\
\hline Hostile (Indicator) & 272 & 0.324 & 0 & 0.469 & 0 & 1 \\
\hline All Cash (Indicator) & 272 & 0.728 & 1 & 0.446 & 0 & 1 \\
\hline Relative Size (Ratio) & 269 & 0.570 & 0.311 & 0.667 & 0.010 & 2.457 \\
\hline Toehold & 272 & 0.087 & 0.004 & 0.107 & 0 & 0.488 \\
\hline Competing (Indicator) & 272 & 0.118 & 0 & 0.323 & 0 & 1 \\
\hline Board Size & 272 & 6.790 & 6 & 2.546 & 3 & 20 \\
\hline NED & 272 & 0.745 & 0.778 & 0.150 & 0.200 & 1.000 \\
\hline Director Ownership(\%) & 272 & 0.356 & 0.025 & 2.906 & 0 & 39.112 \\
\hline
\end{tabular}

Bid premium is the ratio of the final offer price to the target stock price eight weeks prior to the original announcement date minus one. $C A R_{(-1,+1)}$ is the cumulative abnormal return over the 3 -day event window $(-1,+1)$, estimated using market adjusted returns. $C A R_{(-2,+2)}$ is the cumulative abnormal return over the 5-day event window $(-2,+2)$, estimated using market adjusted returns. $C O P$ Total is an indicator variable which takes the value of one if the offer price was increased following a negative market reaction to the takeover announcement (based on 3-day CARs), and zero otherwise. $C O P$ Positive / Negative are indicator variables, partitioned based on the direction of the 3day CARs, which take the value of one if the offer price was increased following a positive/negative market reaction to the takeover announcement, and zero otherwise. NED to CEO comp. is the ratio of average NEDs' total compensation relative to the total CEO's compensation, winsorised at the 5\% level. Industry Expert NEDs is an indicator variable which takes the value of one if any of the NEDs on the bidding firm hold other directorships in the same industry as the target firm, and zero otherwise. Leverage is the ratio of total debt to total assets for the bidding firm at the end of the year prior to the acquisition, winsorised at the 5\% level. Market-to-Book is the ratio of market capitalisation of the bidding firm relative to the book value of equity at the end of the year prior to the acquisition, winsorised at the 5\% level. Target_FCF is the difference between the cash flow from operations and cash flow from investments for the target firm scaled by total assets in the year prior to the acquisition, winsorised at the 5\% level. Bidder_FCF is the difference between the cash flow from operations and cash flow from investments for the bidding firm scaled by total assets in the year prior to the acquisition, winsorised at the 5\% level. $R O A$ is the ratio of net profit to total assets for the target firm in the year prior to the acquisition, winsorised at the 5\% level. Hostile is an indicator variable taking the value of one if the initial recommendation by the target firm directors was to reject the offer, and zero otherwise. All cash is an indicator variable which takes the value of one for takeovers in which the payment method is cash only, zero otherwise. Relative Size is the ratio of the target firm's market capitalisation to the bidding firm's market capitalisation at the end of the financial year prior to the acquisition, winsorised at the 5\% level. Toehold is the percentage share ownership of the bidding firm at the date of the announcement of the acquisition. Competing is an indicator variable which takes the value of one if there are multiple bidders for the same target within a 6-month period of the takeover announcement, and zero otherwise. Board Size represents the number of directors on the bidding firm board at the announcement date of the acquisition. $N E D$ is the fraction of bidding firm board that are non-executive. Director Ownership is the percentage share ownership of the bidding firm directors at the date of the takeover. 


\begin{tabular}{|c|c|c|c|c|c|c|c|c|c|c|c|c|c|c|c|c|c|c|c|c|}
\hline \multicolumn{21}{|c|}{ Table 3 - Pearson Correlation Matrix } \\
\hline & 1 & 2 & 3 & 4 & 5 & 6 & 7 & 8 & 9 & 10 & 11 & 12 & 13 & 14 & 15 & 16 & 17 & 18 & 19 & 20 \\
\hline $\begin{array}{l}\text { 1. } \log (\text { Bid Premium } \\
+1)\end{array}$ & 1 & & & & & & & & & & & & & & & & & & & \\
\hline 2. $\mathrm{CAR}_{(-1,+1)}$ & -0.147 & 1 & & & & & & & & & & & & & & & & & & \\
\hline 3. COP Total & 0.159 & -0.198 & 1 & & & & & & & & & & & & & & & & & \\
\hline 4. COP Positive & 0.122 & 0.196 & -0.108 & 1 & & & & & & & & & & & & & & & & \\
\hline 5. COP Negative & 0.159 & -0.197 & 1.000 & -0.108 & 1 & & & & & & & & & & & & & & & \\
\hline 6. NEDtoCEOcomp. & -0.130 & 0.110 & -0.060 & -0.121 & -0.060 & 1 & & & & & & & & & & & & & & \\
\hline 7. Ind & -0.077 & 52 & -0 & -0 & -0.055 & -0.052 & 1 & & & & & & & & & & & & & \\
\hline 8. Le & -0 & 0.068 & 5 & 0 & 5 & 52 & -0.226 & 1 & & & & & & & & & & & & \\
\hline to Book & 0.162 & 92 & & 0.028 & & 990 & 0.076 & 0.032 & 1 & & & & & & & & & & & \\
\hline 10 & 0 & -0 & -0 & 0. & 4 & 8 & 4 & 0 & 0.057 & 1 & & & & & & & & & & \\
\hline 11 & & -0 & & -0 . & & & & & & & 1 & & & & & & & & & \\
\hline 12. $\mathrm{R}$ & 1 & 0 & & 0.065 & & & -0 & 0. & & & 0.208 & 1 & & & & & & & & \\
\hline & & 0.013 & & 0 & & & 0 & -0 & 6 & & 77 & 0.009 & 1 & & & & & & & \\
\hline 1 & -4 & 0 & & -0 & -0.13 & & 0 & -0 & & & -0 & -0 & 0.03 & 1 & & & & & & \\
\hline ze & -0 & & & -0. & & & & & & & -0. & & & 0.232 & 1 & & & & & \\
\hline 16 & 0 & 0.00 & & 0.1 & -0.13 & 4 & 0.0 & -0.055 & -0.060 & 0.0 & 0.0 & -0 & 0. & -0 & -0.254 & 1 & & & & \\
\hline & -0 & & & & & & -0 & 0 & & & 0 & & & & & -0.032 & 1 & & & \\
\hline & 0. & -0. & & 0.0 & 0. & -0 & -0 & & & & 0.0 & & & & & & 0.06 & 1 & & \\
\hline 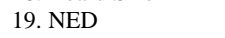 & -0. & -0.07 & & -0.0 & & -0 . & -0. & & & -0. & -0.0 & & & & & & & & 1 & \\
\hline 20. Dir. Ownership & -0.019 & -0.076 & 0.140 & -0.025 & 0.140 & -0.056 & 0.125 & 0.055 & 0.106 & 0.010 & -0.032 & 0.045 & 0.119 & 0.054 & -0.004 & -0.004 & -0.035 & 0.044 & 0.112 & 1 \\
\hline \multicolumn{21}{|c|}{ 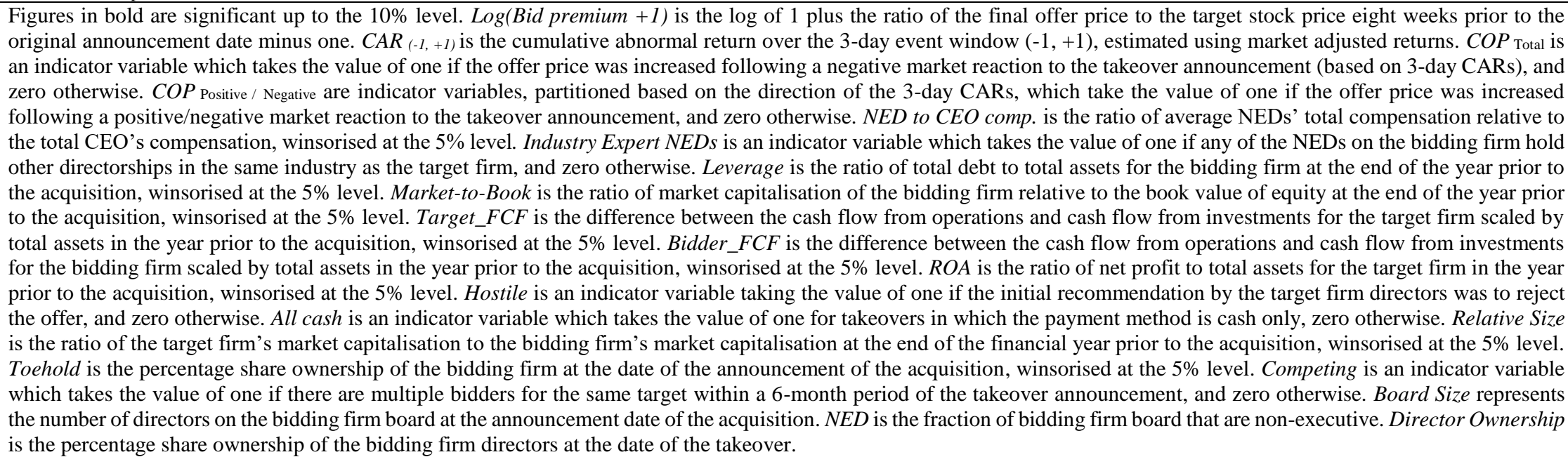 } \\
\hline
\end{tabular}




\begin{tabular}{|c|c|c|}
\hline \multicolumn{3}{|c|}{ 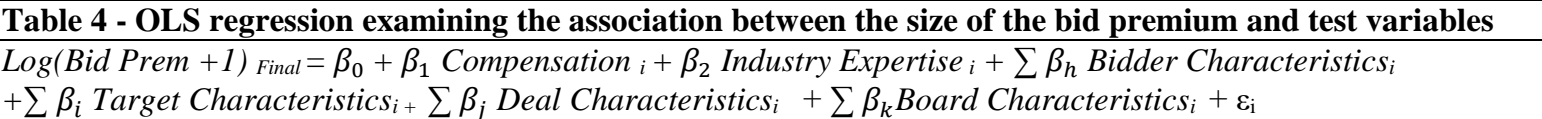 } \\
\hline Variable & Predictions & (1) Log (Bid Premium +1) \\
\hline NED to CEO comp. & - & $\begin{array}{l}-1.805^{*} \\
(-1.68)\end{array}$ \\
\hline Ind. Expert NEDs & - & $\begin{array}{l}-0.187 * \\
(-1.96)\end{array}$ \\
\hline Leverage & - & $\begin{array}{l}-0.087 \\
(-0.26)\end{array}$ \\
\hline Market to Book & + & $\begin{array}{l}0.029 * * \\
(2.51)\end{array}$ \\
\hline Target_FCF & + & $\begin{array}{l}0.049 \\
(0.17)\end{array}$ \\
\hline Bidder_FCF & + & $\begin{array}{l}0.189 \\
(0.62)\end{array}$ \\
\hline ROA & + & $\begin{array}{l}-0.110 \\
(-0.40)\end{array}$ \\
\hline Hostile & + & $\begin{array}{l}0.093 \\
(0.49)\end{array}$ \\
\hline All Cash & - & $\begin{array}{l}-0.222 \\
(-1.41)\end{array}$ \\
\hline Relative Size & + & $\begin{array}{l}-0.025 \\
(-0.21)\end{array}$ \\
\hline Toehold & - & $\begin{array}{l}-0.416 \\
(-0.48)\end{array}$ \\
\hline Competing & + & $\begin{array}{l}-0.232 * \\
(-1.72)\end{array}$ \\
\hline Board Size & + & $\begin{array}{l}-0.024 \\
(-0.84)\end{array}$ \\
\hline NED & - & $\begin{array}{l}0.202 \\
(0.29)\end{array}$ \\
\hline Dir. Ownership & - & $\begin{array}{l}-0.006 \\
(-0.60)\end{array}$ \\
\hline Constant & & $\begin{array}{l}0.606 \\
(0.89)\end{array}$ \\
\hline \multicolumn{2}{|l|}{$\mathrm{N}$} & 176 \\
\hline \multicolumn{2}{|l|}{ R-Squared } & 0.0702 \\
\hline \multicolumn{2}{|l|}{ F Value } & $2.00 * *$ \\
\hline \multicolumn{3}{|c|}{ 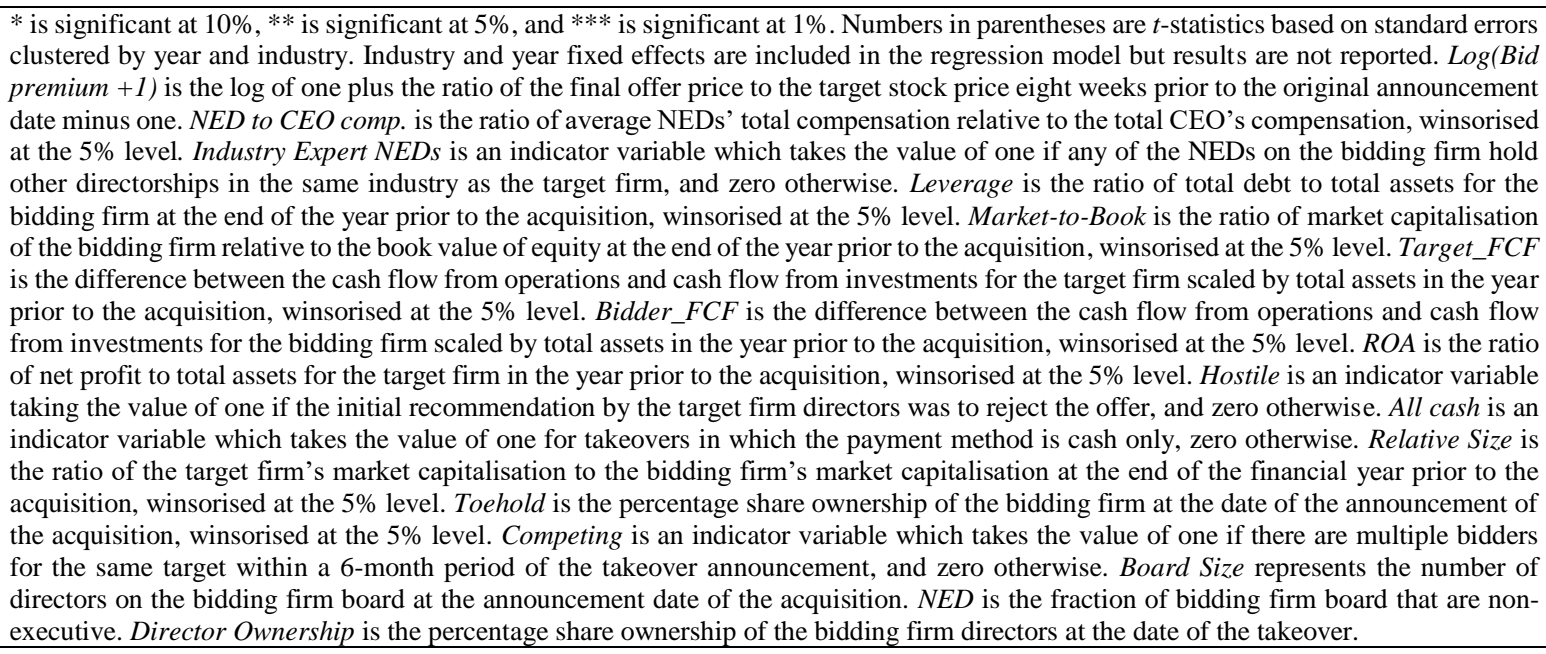 } \\
\hline
\end{tabular}




\begin{tabular}{|c|c|c|c|}
\hline \multicolumn{4}{|c|}{$\begin{array}{l}\text { CAR }(-1,+1)=\beta_{0}+\beta_{1} \text { Compensation } i+\beta_{2} \text { Industry Expertise } i+\sum \beta_{h} \text { Bidder Characteristics } \text { B }_{i} \\
+\sum \beta_{i} \text { Target Characteristics } s_{i}+\sum \beta_{j} \text { Deal Characteristics } s_{i}+\sum \beta_{k} \text { Board Characteristics }_{i}+\varepsilon_{i}\end{array}$} \\
\hline Variable & Predictions & (1) 3-day & (2) 5-day \\
\hline NED to CEO comp. & + & $\begin{array}{l}\mathbf{0 . 1 4 5} * \\
(1.87)\end{array}$ & $\begin{array}{l}\mathbf{0 . 2 5 9} * * * \\
(3.32)\end{array}$ \\
\hline Ind. Expert NEDs & + & $\begin{array}{l}-0.003 \\
(-0.20)\end{array}$ & $\begin{array}{l}-0.002 \\
(-0.07)\end{array}$ \\
\hline Leverage & + & $\begin{array}{l}0.033 \\
(0.95)\end{array}$ & $\begin{array}{l}0.022 \\
(0.48)\end{array}$ \\
\hline Market to Book & - & $\begin{array}{l}0.000 \\
(0.14)\end{array}$ & $\begin{array}{l}0.001 \\
(0.57)\end{array}$ \\
\hline Target_FCF & + & $\begin{array}{l}-0.013 \\
(-0.29)\end{array}$ & $\begin{array}{l}-0.038 \\
(-0.58)\end{array}$ \\
\hline Bidder_FCF & - & $\begin{array}{l}-0.041 \\
(-1.24)\end{array}$ & $\begin{array}{l}-0.035 \\
(-1.11)\end{array}$ \\
\hline ROA & + & $\begin{array}{l}0.013 \\
(0.57)\end{array}$ & $\begin{array}{l}0.005 \\
(0.20)\end{array}$ \\
\hline Hostile & - & $\begin{array}{l}0.002 \\
(0.11)\end{array}$ & $\begin{array}{l}0.020 \\
(0.84)\end{array}$ \\
\hline All Cash & + & $\begin{array}{l}-0.006 \\
(-0.66)\end{array}$ & $\begin{array}{c}-0.011 \\
(-0.61)\end{array}$ \\
\hline Relative Size & - & $\begin{array}{l}0.012 \\
(1.12)\end{array}$ & $\begin{array}{l}0.030 \\
(1.62)\end{array}$ \\
\hline Toehold & + & $\begin{array}{l}0.061 \\
(1.04)\end{array}$ & $\begin{array}{l}0.037 \\
(0.72)\end{array}$ \\
\hline Competing & - & $\begin{array}{l}0.040 \\
(1.32)\end{array}$ & $\begin{array}{l}0.054 * * \\
(2.06)\end{array}$ \\
\hline Board Size & $+/-$ & $\begin{array}{l}0.000 \\
(0.16)\end{array}$ & $\begin{array}{l}-0.002 \\
(-1.11)\end{array}$ \\
\hline NED & + & $\begin{array}{l}-0.074 * \\
(-1.93)\end{array}$ & $\begin{array}{l}-0.029 \\
(-0.27)\end{array}$ \\
\hline Dir. Ownership & + & $\begin{array}{l}-0.002 * * \\
(-2.03)\end{array}$ & $\begin{array}{l}-0.002 * * * \\
(-28.79)\end{array}$ \\
\hline Constant & & $\begin{array}{l}0.024 \\
(0.80)\end{array}$ & $\begin{array}{l}0.007 \\
(0.19)\end{array}$ \\
\hline $\begin{array}{l}\mathrm{N} \\
\text { R-Squared } \\
\text { F Value }\end{array}$ & & $\begin{array}{l}178 \\
0.0912 \\
4.02 * * *\end{array}$ & $\begin{array}{l}167 \\
0.1330 \\
7.82 * * *\end{array}$ \\
\hline \multicolumn{4}{|c|}{ 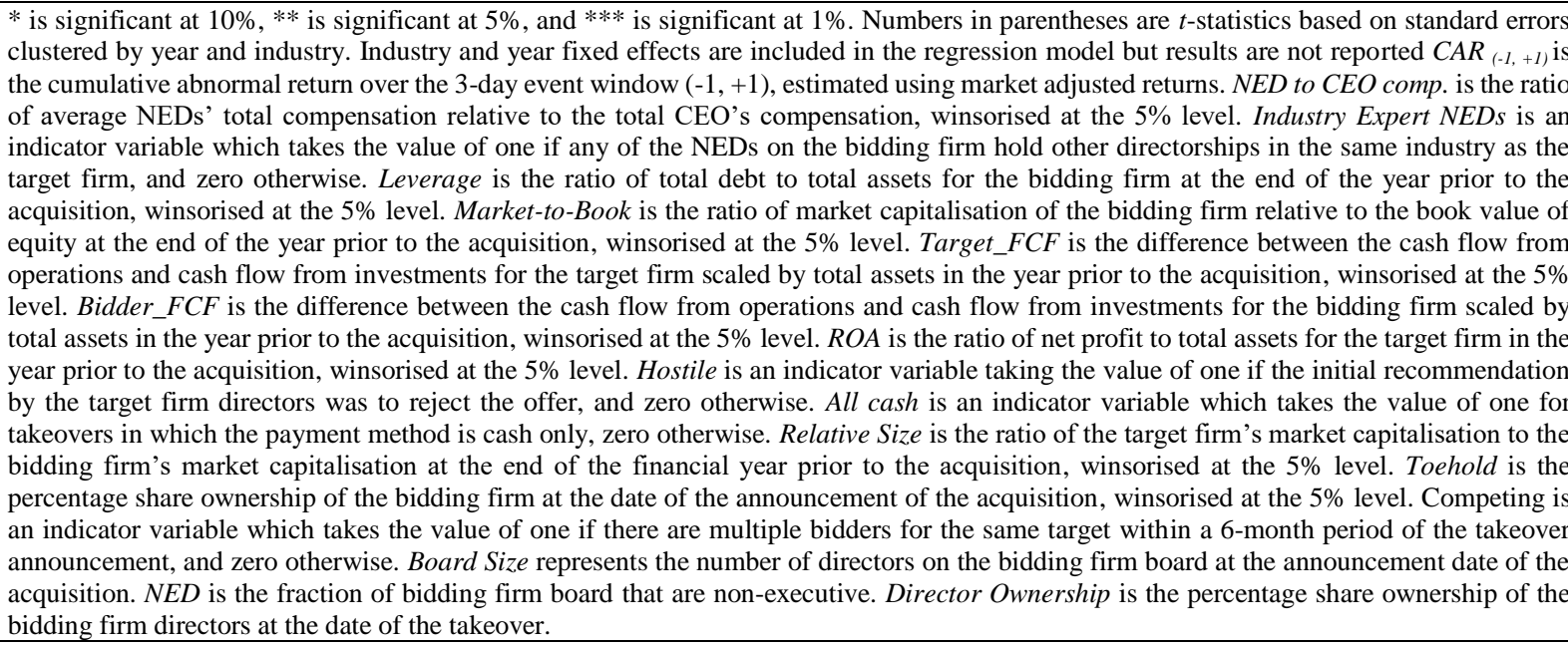 } \\
\hline
\end{tabular}




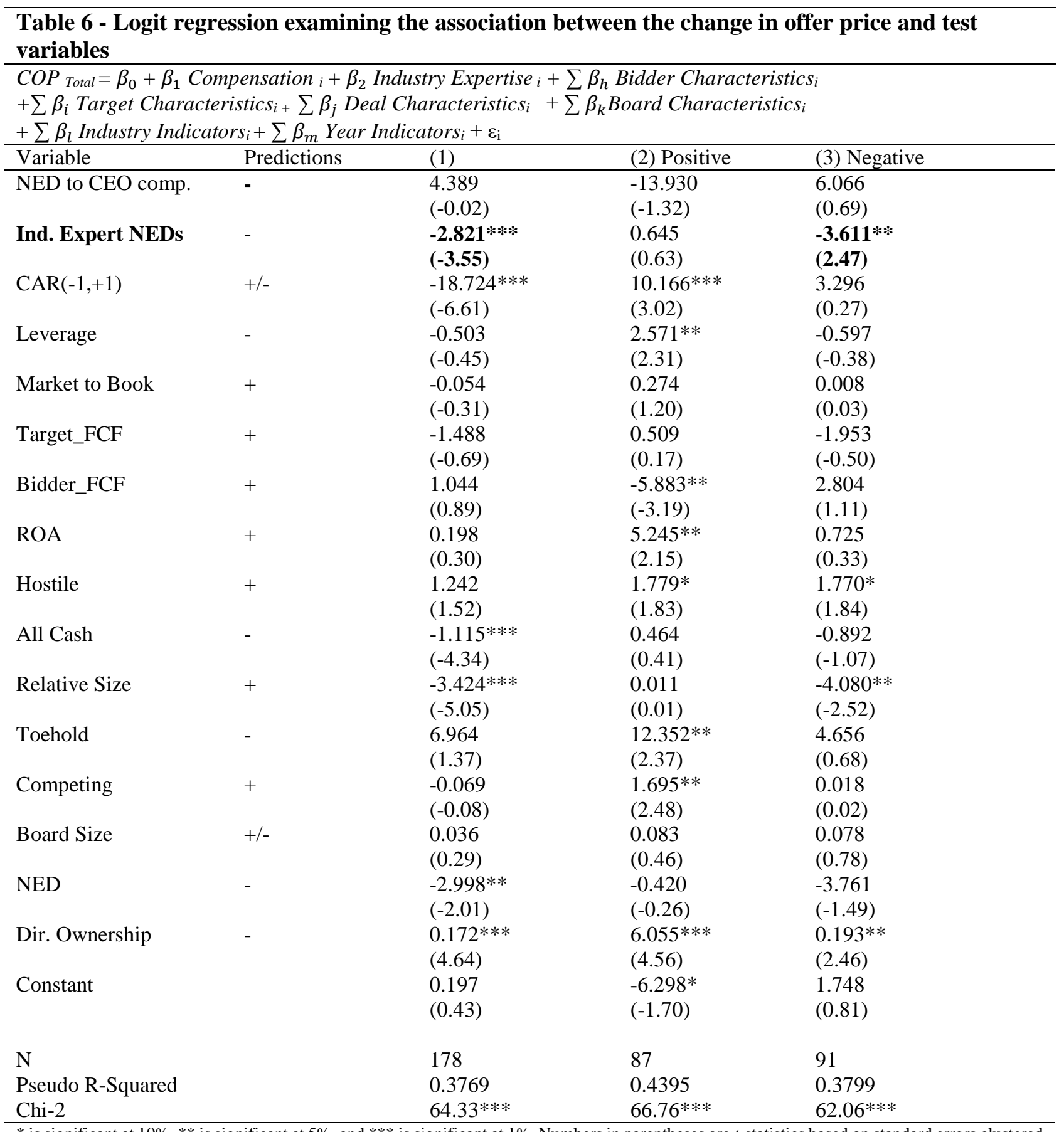

$*$ is significant at $10 \%$, ** is significant at $5 \%$, and $* * *$ is significant at $1 \%$. Numbers in parentheses are $t$-statistics based on standard errors clustered by year and industry. Industry and year fixed effects are included in the regression model but results are not reported $C O P$ Total is an indicator variable which takes the value of one if the offer price was increased following a negative market reaction to announcement (based on 3-day CARs), and zero otherwise. $C O P P_{\text {Positive / Negative }}$ are indicator variables, partitioned based on the direction of the 3-day CARs, which take the value of one if the offer price was increased following a positive/negative market reaction to the takeover announcement, and zero otherwise. $C A R_{(-I,+1)}$ is cumulative abnormal return over the 3 -day event window $(-1,+1)$, estimated using market adjusted returns. NED to CEO comp. is the ratio of average NEDs' total compensation relative to the total CEO's compensation, winsorised at the 5\% level. Industry Expert NEDs is an indicator variable which takes the value of one if any of the NEDs on the bidding firm hold other directorships in the same industry as the target firm, and zero otherwise. Leverage is the ratio of total debt to total assets for the bidding firm at the end of the year prior to the acquisition, winsorised at the 5\% level. Market-to-Book is the ratio of market capitalisation of the bidding firm relative to the book value of equity at the end of the year prior to the acquisition, winsorised at the 5\% level. Target_FCF is the difference between the cash flow from operations and cash flow from investments for the target firm scaled by total assets in the year prior to the acquisition, winsorised at the 5\% level. Bidder_FCF is the difference between the cash flow from operations and cash flow from investments for the bidding firm scaled by total assets in the year prior to the acquisition, winsorised at the $5 \%$ level. $R O A$ is the ratio of net profit to total assets for the target firm in the year prior to the acquisition, winsorised at the 5\% level. Hostile is an indicator variable taking the value of one if the initial recommendation by the target firm directors was to reject the offer, and zero otherwise. All cash is an indicator variable which takes the value of one for takeovers in whiceh the payment method is cash only, zero otherwise. Relative Size is the ratio of the target firm's market capitalisation to the bidding firm's market capitalisation at the end of the financial year prior to the acquisition, winsorised at the 5\% level. Toehold is the percentage share ownership of the bidding firm at the date of the announcement of the acquisition, winsorised at the 5\% level. Competing is an indicator variable which takes the value of one if there are multiple bidders for the same target within a 6-month period of the 
takeover announcement, and zero otherwise. Board Size represents the number of directors on the bidding firm board at the announcement date of the acquisition. NED is the fraction of bidding firm board that are non-executive. Director Ownership is the percentage share ownership of the bidding firm directors at the date of the takeover. 